\title{
A Fly That Has No Counselor Will Follow the Corpse to the Grave: Nigerian Culture's Influence on Negotiation
}

\author{
Samuel A. Spralls III \\ Central Michigan University \\ Obinna Obilo \\ Central Michigan University \\ Michael Garver \\ Central Michigan University \\ Richard Divine \\ Central Michigan University
}

\begin{abstract}
Gaining global economic advantages in the current era involves transcending national borders and forming collaborative business relationships within frontier markets such as Nigeria. The negotiations mandated by these relationships are highly culturally-dependent as such, foreign entities must learn the Nigerian negotiating style before engaging in business within the nation. We thus present, in this research, a profile of the Nigerian negotiating style. We empirically test a previously published series of propositions on the Nigerian negotiation profile and find that even though higher status negotiators are desired, informal and collectivistic/consensus-driven negotiations that result in complex agreements are preferred.
\end{abstract}

Keywords: International Business Negotiations, Cross-cultural Negotiations, Negotiating with the Nigerians, Negotiation orientation, Negotiating Tendencies, Negotiating Style, Negotiator's Profile

\section{INTRODUCTION}

To acquire and maintain competitive advantage, amidst globalization and economic interdependence (Mahajan, 2009; Ndulu, 2007), firms are increasingly forming collaborative agreements with companies in Nigeria, the most populated country in sub-Saharan Africa (Ndulu, 2007; Nwankwo, 2000; Rudd \& Lawson, 2007). This international business negotiation can be further characterized as "the deliberate interaction of two or more social units (at least one of them a business entity), originating from different nations, that are attempting to define or redefine their interdependence in a business matter," (Weiss, 1993, p. 270). It follows, then, that culture is a crucial determinant of negotiating style (Graham, Mintu, \& Rogers, 1994; Luomala, Kumar, Singh, \& Jaakkola, 2015). As Luomala et al. (2015, p. 539) put it, 
"negotiators embedded in different cultures approach negotiations differently." Because of the complexities inherent in cross-cultural negotiations (Adair \& Brett, 2005; Brett, 2000; Bulow \& Kumar, 2011; Gelfand et al. 2013; Sawyer \& Guetzkow, 1965), U.S. negotiators, seeking to do business in Nigeria, should learn the negotiating style of their counterpart's culture, i.e., the Nigerian negotiator's profile (Brett, 2000).

Unfortunately, the Nigerian negotiator's profile is not well specified (Acuff, 1997; Gelfand \& Dyer, 2000; Metcalf, Bird, \& Dewar, 2008; Salacuse, 1998, \& Weiss \& Stripp, 1998) and has not been addressed in any empirical study to date (Luomala et al., 2015; Spralls, Okonkwo, \& Akan, 2011). This is remarkable given that context is critical and negotiation strategy must depend on the specific situation (Eliasberg, Lilien, \& Kim, 1995). Spralls et al. (2011) offered an integrated framework that attempts to capture the Nigerian negotiator's profile. The framework combines insights from Weiss and Stripp's $(1985,1998)$ model of culture's effect on negotiating style and ten African values and beliefs put forth by Onwuejeogwu (1995). Additionally, the authors advance propositions pertaining to Nigerian Culture's Influence on negotiation. However, as they point, these propositions require empirical validation.

The purpose of this research is to examine the interaction between Nigerian culture and the process of negotiation. Based on the propositions put forth in Spralls et al. (2011), we posit a series of hypotheses to be tested in this study. Thus, we revisit each individual dimension within the Nigerian Negotiator's Profile (Spralls et al., 2011) and put forth hypotheses for each of the 12 dimensions. Our contributions with this effort are twofold: we contribute to the conceptual domain by expanding on the work of Spralls et al. (2011), and to practice, by creating utility for managers and business owners planning to do business in Nigeria or with Nigerians, by shedding light on the predominant Nigerian negotiating style they are likely encounter.

Our article is organized as follows. First, we briefly review research that provides the background for the theoretical underpinnings of the proposed framework and discuss hypotheses regarding the Nigerian cultural dimensions and attributes that likely influence negotiations. Next, a field investigation, undertaken in Nigeria, is described, followed by a discussion of the research results. The article concludes with a discussion of the theoretical and practical implications of the findings and directions for future research.

\section{THEORETICAL FRAMEWORK}

\section{International Business Negotiation}

The comparative microbehavioral stream, within international business negotiations, centers on bargaining between individuals in different cultures (e.g., Cellich \& Jain, 2004; Sawyer \& Guetzow, 1965) and provides the conceptual basis for our study. Microbehavioral researchers explore the negotiation process, outcomes, and background factors such as culture. Previous research in this area has focused on intercultural negotiation (Bernard, 2013; Brett, 2000, 2007; Luomala et al., 2015; Okoro \& Day, 2013) and various negotiating styles (Binnendijik, 1987; Egunjobi \& Odiaka, 2015; Fang, 1998; Faure, 1998; Ghauri, \& Fang, 2001; Tung, 1982). By exploring the different negotiating styles business people seeking to successfully do business in Nigeria will have to adopt, the current study contributes to both extant research streams mentioned above. Because of Nigeria's diversity, however, it simply does not make sense to discuss Nigerian culture as a whole (Weiss \& Stripp, 1998). We thus also consider ethnic culture (Rudd \& Lawson, 2007). There are three major ethnic groups in Nigeria: Hausa-Fulani $(29 \%)$, Yoruba (21\%), and Igbo (18\%), we focus on the Igbo because they are considered the dominant entrepreneurs in Nigeria (Spralls et al., 2011).

\section{Nigerian Igbo Culture}

Culture-entrepreneurship research (e.g., Katwalo \& Madichie, 2008) provides support for the existence of an "entrepreneurial culture" trait that is thought to drive entrepreneurship development. Madichie, Nkamnebe, and Idemobi (2008, p. 287), citing Gibb (1996), defined entrepreneurial culture as "a conglomeration of values, beliefs, and attitude that are identical in a particular society, which has the 
propensity to drive entrepreneurial inclination of that society both at the micro (individual) and macro levels." A logical extension of this thinking is that these core values and beliefs affect negotiating style as well (Egunjobi \& Odiaka, 2015; Janosik, 1987; Munene, Schwartz, \& Smith, 2000; Spralls et al., 2011).

The Igbos, as mentioned, are considered to be the dominant entrepreneurs in Nigeria (Spralls et al., 2011); as Brautigam (1997, p. 1072), citing Achebe (1983, p. 43) notes "The Igbo culture, being receptive to change, individualistic and highly competitive, gave the Igbo man an unquestioned advantage over his compatriots in securing advancement in Nigerian colonial society." The Igbos (hereafter, simply Nigerians) are thus most likely to possess the "entrepreneurial culture" trait, which in turn influences their approach to negotiations.

Although Africans do not share a singular cultural life, they do comprise a meaningful cultural group who share several important values and practices, while allowing for variations in individual and group preferences (Munene et al., 2000). Cultural themes that likely drive African negotiation style thus also likely drive the Nigerian negotiating style (Munene et al., 2000; Onwuejeogwu, 1995; Schwartz, 1999), including: (1) high embeddedness, where meaning in life is achieved largely through social relationships, (2) high hierarchy values, which implies that there is a hierarchical system of assigned roles and values that support and legitimize unequal distribution of power, roles, and resources (Onwumechili, 2018), (3) high mastery or seeking to assert control and exploit it to further individual or group interests (Egunjobi \& Odiaka, 2015), (4) low egalitarianism, which means Africans do not view individuals as moral equals having basic interests in common, and (5) low intellectual autonomy that centers on the rights of individuals to follow their own intellectual directions.

Applying the themes above and building on the work of Weiss and Stripp (1998) and Salacuse (1998) among others, Spralls et al. (2011) put forth a series of propositions regarding the Nigerian negotiator's profile. We thus revisit these propositions and respond to the call to empirically test them.

\section{Nigerian Culture and Intercultural Negotiations: Developing Research Hypotheses}

Based on the propositions put forth in Spralls et al. (2011), on the interaction between Nigerian culture and the process of negotiation, we posit a series of hypotheses to be tested in this research.

\section{Basic Concept of the Negotiating Process}

Broadly speaking, the basic concept of the negotiating process is either distributive or integrative. Distributive negotiators view the negotiation as win/lose, that is, in order for them to win, someone must lose (Metcalf et al., 2008). On the other hand, negotiators with an integrative profile, view negotiation as win/win and therefore seek mutually beneficial solutions (Bazerman \& Neale, 1992). Like Salacuse (1998) and Weiss (1998), we expect that Nigerians tend to be distributive given that they are high in mastery and seek to maximize tribal interests (Munene et al., 2000). Thus, we assert that Nigerian negotiators seek to maximize the in-group goals and interests, to the detriment of the non-group members (Spralls et al., 2011). We thus posit that:

\section{$\boldsymbol{H}_{1}$ : Nigerian negotiators will display a higher affinity for the distributive rather than integrative} negotiating concept.

\section{Most Significant Type of Issue}

Negotiators tend to be either relational or task oriented as evidenced by what they spend the most time on (Metcalf et al., 2008; Weiss \& Stripp, 1998). Nigerians likely view building a relationship based on trust and commitment (Morgan \& Hunt, 1994) as a foundation for task-related issues (Egunjobi \& Odiaka, 2015; Spralls et al., 2011). Further, research (e.g., Moran \& Stripp, 1991) supports the assertion that Nigerian negotiators put more value in relationship development over focusing primarily on the task at hand (Acuff, 1997; Weiss \& Stripp, 1998) as such, we posit that:

$\boldsymbol{H}_{2}$ : Nigerian negotiators will display a higher affinity for relational over task-related issues. 


\section{Selection of Negotiators}

When it comes to selecting negotiators, the extant research shows that in highly hierarchical cultures such as the Nigerian, assignment of crucial roles and resources are based on some element of status rather than ability (Salacuse, 1998; Schwartz, 1999). For example, the elder, among Nigerians is greatly respected and age is tied to knowledge and wisdom (Okoro \& Day, 2013; Weiss \& Stripp, 1998). Parallel with the literature (e.g., Salacuse, 1998; Weiss \& Stripp, 1998), we posit that:

$\boldsymbol{H}_{3}$ : Nigerians will display a preference for lead negotiator selection based on status elements such as age or years of experience, rather than by education or superior ability.

\section{Influence of Individuals' Aspirations}

This variable captures the extent to which people, within a culture, strive for individual goals, objectives, and personal recognition (Metcalf et al., 2008). When exploring the influence of individuals' aspirations in solution-seeking, the overwhelming view is that Nigerians tend to be collectivistic rather than being driven to satisfy their own individual desires (Brett, 2000; Nnadozie, 1998; Salacuse, 1998). We thus posit that:

\section{$\boldsymbol{H}_{4}$ : Nigerian negotiators will tend to prefer collectivistic over individualistic solutions.}

\section{Decision-Making in Groups}

Decision-making in groups refers to whether decisions are made by a leader, e.g., tribal chief, or by a group majority (Brett, 2000). Although the hierarchical culture of Nigeria suggests that a top-down approach would be prevalent, Spralls et al. (2011) argue that since Nigerians link success and advancement to allegiance to powerful groups and individuals, they would be more apt to insist that all negotiation decisions must receive the 'nod' of all representative factions. In this vein, we propose:

$\boldsymbol{H}_{5}$ : Nigerian negotiators will display a preference for consensus-building over centralized decisionmaking processes.

\section{Orientation Toward Time}

On the relationship with time dimension (i.e., chronemics), polychronic cultures are generally more flexible with time whereas monochromic cultures believe that negotiation issues should be resolved during the scheduled time period (Metcalf et al., 2008). Nigerians have been shown to have a relaxed attitude toward time (Spralls et al., 2011; Weiss \& Stripp, 1998) and are thus more likely to be polychronic with time. We thus posit that:

\section{$\boldsymbol{H}_{6}$ : Nigerian negotiators will display a polychronic over a monochronic time-orientation.}

\section{Risk-Taking Propensity}

Considering risk-taking propensity, the research suggests that Nigerians are generally risk-tolerant (Salacuse, 1998), as they are quite willing to take risks for short-term gains (Weiss \& Stripp, 1998). Whether the driving factor is an embedded cultural optimism (Onwuejeogwu, 1995) or a sense of limited time to achieve (Mahajan, 2009), we posit that:

\section{$\boldsymbol{H}_{7}:$ Nigerian negotiators will be more risk-tolerant than risk-averse.}

\section{Speed of Trust}

The literature largely focuses on how trust is formed and where it resides (Metcalf et al., 2008). For example, people may trust the other side because they have a signed contract (i.e., external trust). On the other hand, trust may be internal to the relationship, that is, party A believes that party B is reliable, has integrity, and is benevolent towards them (Morgan \& Hunt, 1994). We find it productive to depart from 
this view when considering Nigerian culture. For Nigerians, the contract may serve as: (1) a symbol of the relationship (Onwuejeogwu, 1995), (2) a record of the understanding, and (3) a possible means of recourse should things go "left" (Weiss \& Stripp, 1998). Indeed, foreigners doing business in Nigeria, should be aware that contracts in Nigeria may not carry the same weight as they may have in the U.S. Summarizing to this point and from the perspective of this study, it may be more important to determine the speed of trust rather than where it resides.

On the speed of trust dimension, for Nigerians, while a contract is necessary to initiate the trust formation process, it is not sufficient in and of itself (Madicie et al., 2008; Salacuse, 1998). As mentioned, Nigerian negotiators put a lot of stock in relationship development (Weiss \& Stripp, 1998; Spralls et al., 2011); this relational focus causes Nigerian negotiators to thus spend time in developing relationships ergo trust. As such, we posit that:

$\boldsymbol{H}_{8}$ : Nigerian negotiators will exhibit a preference for slower rather than faster speed of trust.

\section{Concern with Protocol}

This dimension is concerned with the extent to which the rules of social behavior and selfpresentation are important to individuals within a culture. For example, cultures high/low in concern for negotiation etiquette are considered formal/informal (Metcalf et al., 2008). Due to the hierarchical nature of Nigerian culture, behaviors such as the manner of speaking, manner of dress, addressing higher status individuals by titles etc. are given the utmost importance (Adler, 2002; Metcalf et al., 2008). We thus posit that on the concern with protocol dimension:

\section{$\boldsymbol{H}_{9:}$ Nigerian negotiators will exhibit a higher preference for formal over informal protocol.}

\section{Communication Style}

Concerning communication style, cultures generally fall somewhere on the low-context vs. highcontext communication dichotomy. Low-context cultures prefer explicit and unambiguous communication and might be viewed as more confrontational compared to a high-context communicator, who relies on indirect and implicit communication as well as shared meaning (Gudykunst et al., 1996). Focusing on Nigerians' preference for developing and maintaining relationships, Spralls et al. (2011) suggest that Nigerians will display more high-context communication behaviors, as tact and subtle communications are necessary to maintain relationships, particularly in hierarchical cultures (Okoro \& Day, 2013; Onwumechili, 2018). We thus posit that:

$\boldsymbol{H}_{10}$ : Nigerian negotiators will exhibit a preference for high-context over low-context communication styles.

\section{The Nature of Persuasion}

The nature of persuasion dimension explores whether negotiators employ empirical facts and logic or feelings and beliefs to convince the other side. The extant research asserts that Nigerian negotiators rely on emotion and experience (Metcalf et al., 2008; Nnadozie, 1998) rather than empirical reason (Salacuse, 1998; Weiss \& Stripp, 1998). We thus posit that:

\section{$\boldsymbol{H}_{11}$ : Nigerian negotiators will exhibit a preference for affective over a factual-inductive persuasion style.}

\section{Type of Satisfactory Agreement}

Some researchers have characterized type of satisfactory agreement as centering on whether the contract is explicit or implicit (e.g., Metcalf et al., 2008; Weiss \& Stripp, 1998). However, given Nigerian's emphasis on the relational aspects of the negotiation, it may be more useful to interpret this dimension as referring to the nature and scope of desired outcomes (Nnadozie, 1998; Spralls et al., 2011). Simple agreements are those wherein a simple cash/stock compensation is agreed upon for completed 
work. Complex agreements, on the other hand, include a more convoluted work and compensation structure. Research suggests that while Nigerians view managing relationships as a point of focus, they are more likely to view contracts as flexible (i.e., allow for room to wiggle) and as opportunities to make structural improvements (Nnadozie, 1998; Spralls et al., 2011). As such we posit that:

\section{$H_{12}$ : Nigerian negotiators will prefer complex rather than simple agreements.}

\section{METHOD}

The purpose of this study is to investigate the Nigerian negotiator's profile (Brett, 2000). By better understanding which attributes of negotiation are most like Nigerians, firms seeking to do business in Nigeria can develop more effective negotiating strategies. The research seeks to answer at least three coarse-grained research questions: (a.) which attributes of negotiating style are most like Nigerians? (b.) which attributes of negotiating style are least like Nigerians? And (c.) what is the Nigerian negotiator's profile?

To address the study purpose and research questions, a maximum difference scaling (MDS) pencil and paper survey was developed and administered to a sample of Nigerian MBA and MBA-level college students. MDS is an extension of the method of paired comparisons, which has long been respected as a rigorous technique that yields reliable and valid data (Chrzan \& Golovashkina, 2006). In MDS, the respondent is typically shown four or five items, with the task of selecting the most preferred or important and least preferred or unimportant items. The respondents' choices result in mean importance scores for all the assessed attributes. In the current research context, we note that the higher the score, the more the attribute is 'like' the respondents and vice versa. To assess the research hypotheses, we simply compared the resultant scores for the attribute pairs representing each dimension.

\section{Study Design}

In the current study, we measure the attributes of the Nigerian negotiator's profile as proposed by Spralls et al. (2011) and use them to guide the development of our survey (see Table 1). The researchers chose to include five variables per MDS survey question, an acceptable and recommended practice (Chrzan \& Patterson, 2006). Following Garver et al. (2010), 15 MDS questions were asked to each research participant. Then, an MDS experimental design stage was created which lead to each variable being shown approximately three times each to each survey participant. The actual MDS survey questions contained the following instructions: "When thinking about negotiating with Americans, what attribute is most like you and least like you?" For each of the 15 MDS questions, the research respondents selected the "most like you" and "least like you" variable (see Figure 1). Research suggests (e.g., Weiss \& Stripp $(1985,1998)$ that negotiators will tend to gravitate towards one of the two presented attributes of each dimension. 
TABLE 1

NEGOTIATION DIMENSIONS AND NEGOTIATOR ATTRIBUTES

\begin{tabular}{|c|c|c|}
\hline & ATTRIBUTE LIST & DIMENSION \\
\hline $\begin{array}{l}1 \\
2\end{array}$ & $\begin{array}{l}\text { In order for me to win, the other side must lose } \\
\text { Seeks mutually beneficial solutions }\end{array}$ & $\begin{array}{l}\text { Basic Negotiation } \\
\text { Concept }\end{array}$ \\
\hline 3 & Links both success and advancement to the relationship & Most Significant Issue \\
\hline 4 & A focus on specific issues having to do with the project at hand & Type \\
\hline $\begin{array}{l}5 \\
6\end{array}$ & $\begin{array}{l}\text { Wisdom comes from experience and time, not education } \\
\text { Members should be younger, with superior ability to negotiate }\end{array}$ & Selection of Negotiators \\
\hline $\begin{array}{l}7 \\
8\end{array}$ & $\begin{array}{l}\text { The only true wealth is wealth that is shared with others } \\
\text { Seeks outcomes that are in my own best interest }\end{array}$ & $\begin{array}{l}\text { Influence of Individual } \\
\text { Aspirations }\end{array}$ \\
\hline $\begin{array}{c}9 \\
10\end{array}$ & $\begin{array}{l}\text { No single key decision maker and every member has equal say } \\
\text { One leader approach to negotiating team organization }\end{array}$ & $\begin{array}{l}\text { Decision-Making } \\
\text { Process }\end{array}$ \\
\hline $\begin{array}{l}11 \\
12\end{array}$ & $\begin{array}{l}\text { Time is flexible } \\
\text { Time is money }\end{array}$ & $\begin{array}{l}\text { Orientation Towards } \\
\text { Time }\end{array}$ \\
\hline $\begin{array}{l}13 \\
14\end{array}$ & $\begin{array}{l}\text { Willing to take huge risks for large short-term gains } \\
\text { It is often better to delay a decision than to risk a mistake }\end{array}$ & Risk-Taking Propensity \\
\hline $\begin{array}{l}15 \\
16\end{array}$ & $\begin{array}{l}\text { Develops trust quickly, once a relationship has been established } \\
\text { In general, people cannot be trusted }\end{array}$ & Speed of Trust \\
\hline $\begin{array}{l}17 \\
18\end{array}$ & $\begin{array}{l}\text { The rules of self-presentation and social behavior matter } \\
\text { Little or no concern with negotiation etiquette in social settings }\end{array}$ & Concern with Protocol \\
\hline $\begin{array}{l}19 \\
20\end{array}$ & $\begin{array}{l}\text { Avoids confrontation and conceals ill feelings } \\
\text { Depends on explicit, verbally expressed communications }\end{array}$ & Style of Communication \\
\hline $\begin{array}{l}21 \\
22\end{array}$ & $\begin{array}{l}\text { Draws on empirical facts and if-then logic to convince others } \\
\text { Draws on feelings and religious beliefs to support arguments }\end{array}$ & Nature of Persuasion \\
\hline $\begin{array}{l}23 \\
24\end{array}$ & $\begin{array}{l}\text { Compensation in cash/stock and help with socio-economic conditions } \\
\text { Compensation in cash/check and/or stock }\end{array}$ & $\begin{array}{l}\text { Type of Satisfactory } \\
\text { Agreement }\end{array}$ \\
\hline
\end{tabular}

Originally developed by Weiss \& Stripp $(1985,1998)$ (later updated by Metcalf et al., 2008) as modified by Spralls et al. (2011).

The survey primarily focused on the 12 cultural dimensions of negotiating strategy (Metcalf et al., 2008; Spralls et al., 2011; Weiss \& Stripp 1985, 1998). To assess the Nigerian negotiator's profile as put forth in our hypotheses, 24 statements (shown in Table 1) were utilized to represent each attribute of the 12 dichotomous cultural dimensions. Basic demographic data such as age, gender, occupational experience, and so forth were also collected. 


\section{FIGURE 1 \\ SAMPLE SURVEY MAXDIFF QUESTION}

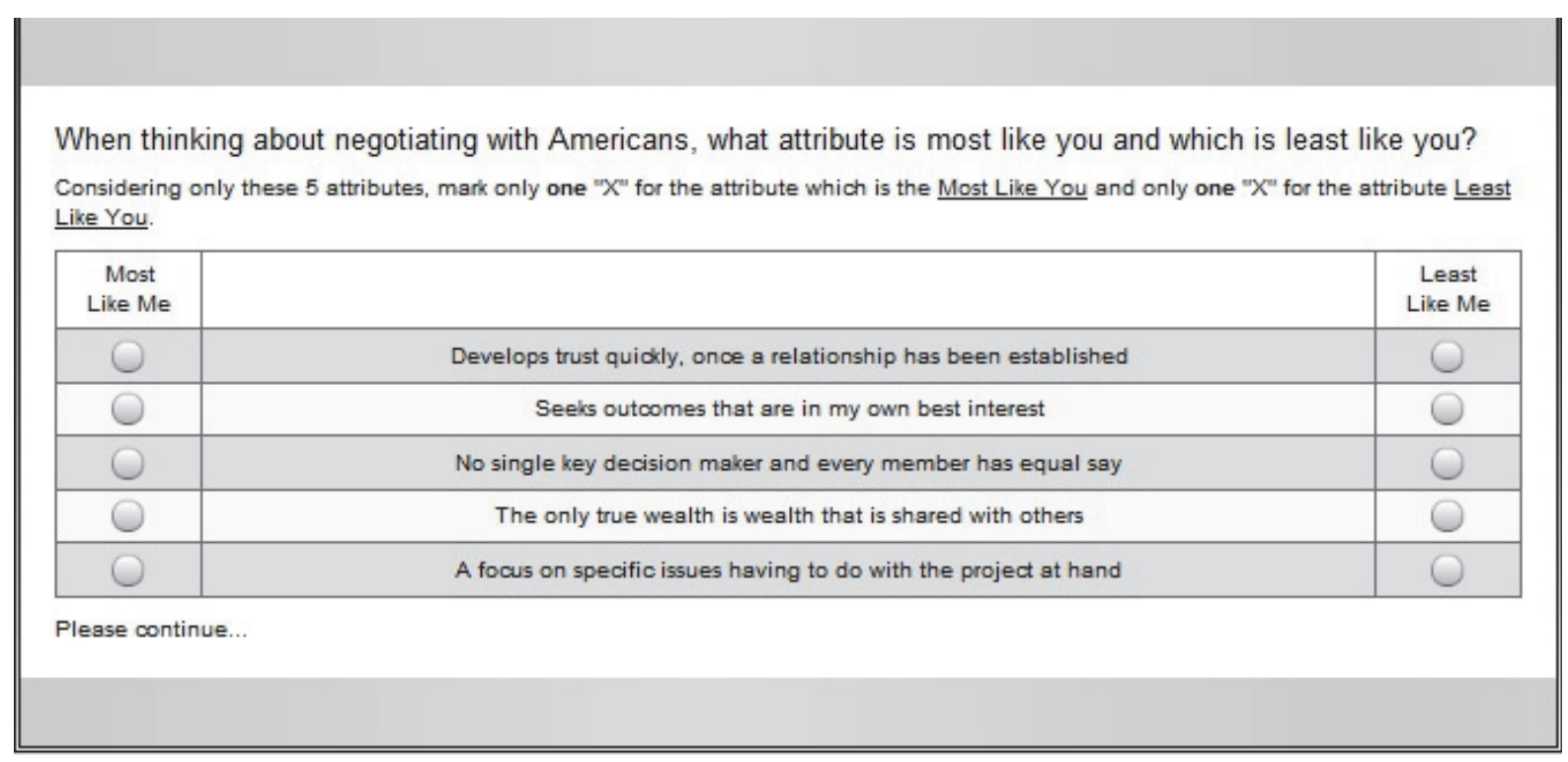

\section{Data Collection}

To collect the data for this research, we drew the sample from three universities in Nigeria, including one prestigious university in Lagos, the main business hub of Africa's largest economy. We decided to focus on a graduate business school sample, as it represents a collection of individuals with varying experiences in the various business sectors of Nigeria.

Before administering the survey, the authors pretested it with 20 Nigerian-born graduate students attending a major midwestern university in the U.S. This allowed us to identify ambiguities in the wording and other issues that might stand in the way of effective measurement. Once pretesting was completed, we sent letters to university administrators at the selected schools to solicit cooperation. All three schools agreed to allow us to survey MBA and MBA level students at their respective schools and provide assistance with the survey. The researchers contacted professors/instructors to explain the selfadministered survey's contents and procedures to minimize research bias.

The survey was administered at each site via paper and pencil and informed consent was obtained via the same method prior to beginning each survey. Participation was entirely voluntary, and no compensation was offered to the respondents. The Nigerian students received a questionnaire written in English, the national language of Nigeria. Therefore, it is likely that language proficiency was not an issue. Sawtooth software (8.0) was used to collect and analyze the MDS data. Specifically, Hierarchical Bayes was implemented to analyze the MDS data.

\section{Results}

205 Nigerian MBA/MBA-level students completed the survey. There were 205 questionnaires distributed and all 205 were returned. Thus, the effective response rate for our sample was $100 \%$. Of those collected questionnaires, 69 were excluded because they were not fully completed and errors in the survey responses (e.g. selecting multiple attributes as "most like me" or "least like me" in a choice set) resulted in the elimination of an additional 14 responses. Thus, there were 122 useable responses. The effective number of observations exceeds the threshold of 100 completed survey respondents for an MDS study (Garver et al., 2010). Graduate student participants, at all three universities, completed the survey during the same two-week period. To our knowledge, there were no events during the two-week period that could have affected student responses. 


\section{Sample Characteristics}

The resulting sample consists of 122 respondents (65\% Male, 35\% Female; 18-24yrs, 3\%; 25-31yrs, $45 \%$; 32-38yrs, 26\%; 39-45yrs, 12\%; 46-52yrs, 13\%; 53yrs and above, 1\%). Thus, the final sample is predominantly younger in nature, with $72 \%$ of the sample being 25 to 38 years of age. The sample also consists of individuals with industry experience across several fields including: agriculture, banking and finance, healthcare, military, oil and gas, telecommunications and so forth. Additionally, respondents had negotiation experience in several fields including: procurement, sales \& purchasing, land deals, general contracts, union contracts, and more. Thus, our sample is likely representative of the types of individuals likely to engage in cross-cultural negotiations with Americans.

\section{MDS Results}

Concerning the analysis of MDS data, Hierarchical Bayes was implemented to analyze the MDS data. The Hierarchical Bayes analysis results are rescaled so that the scores for all variables sum to 100 points, with higher scores reflecting "more like the Nigerian negotiating style" scores and lower scores reflecting "less like the Nigerian negotiating style." Thus, scores for one variable should be interpreted in relative, not absolute terms. Table 2 contains the MDS mean scores for the attributes that collectively characterize the Nigerian negotiating style (i.e., what it is and what it is not) of the final sample.

TABLE 2

MD MEAN SCORES

\begin{tabular}{|l|c|}
\hline \multicolumn{1}{|c|}{ Concepts } & MD Mean Score \\
\hline Integrative & 10.26 \\
\hline Task Related & 8.88 \\
\hline Factual Inductive & 8.31 \\
\hline High Concern for formal Protocol & 7.39 \\
\hline Risk Averse & 7.38 \\
\hline Collectivist & 7.02 \\
\hline Relational & 6.93 \\
\hline Monochronic & 5.70 \\
\hline Fast Trust & 5.31 \\
\hline Consensus & 5.18 \\
\hline Low Context & 4.35 \\
\hline Older & 3.58 \\
\hline Individualist & 2.75 \\
\hline Complex & 2.49 \\
\hline High Context & 2.43 \\
\hline Younger & 2.15 \\
\hline Simple & 1.93 \\
\hline Centralized & 1.74 \\
\hline Polychronic & 1.59 \\
\hline Risk Tolerant & 1.36 \\
\hline Slow Trust & 1.27 \\
\hline Affective & 1.09 \\
\hline Low Concern for formal Protocol & 0.61 \\
\hline Distributive & 0.29 \\
\hline
\end{tabular}

Several observations should be made about the results in Table 2. First, there is excellent discrimination among the different variables, with scores ranging from 0.29 to 10.26 . Second, the seven highest scoring variables (those variables that are "most like" the negotiating style of the final sample) sum to 56.17, which means that these variables (approximately $29 \%$ of the variables) collectively account 
for approximately $56 \%$ of the average Nigerian negotiating style and suggests that American negotiators should focus on these attributes. Analysis of the data in Table 2 reveals the answers to the first research question. That is, the top seven variables that are most like or most representative of the Nigerian negotiating style include the following:

- Integrative (10.26)

- $\quad$ Task Related (8.88)

- Factual Inductive (8.31)

- High Concern for formal Protocol (7.39)

- Risk Averse (7.38)

- Collectivist (7.02)

- Relational (6.93)

Analysis of the data in Table 2 also reveals the answers to the second research question. The results suggest that the Nigerian negotiating style is not characterized as affective (1.09), is not characterized with a low concern for formal protocol and does not seem to be distributive.

- Affective (1.09)

- Low Concern for formal Protocol (0.61)

- Distributive (0.29)

\section{Hypothesis Testing}

To test each of the proposed hypotheses, the researchers employed paired sample t-tests to determine if there was a significant difference in the scores of the two variables, as depicted in the proposed hypotheses. In order for the proposed hypotheses to be accepted, the proposed direction of the difference needs to be correct (i.e., the one variable proposed to have a higher score must actually have a higher score). Thus, in addition to possessing the right direction, the actual difference must be statistically significant. Due to the number of hypotheses being tested, the commonly accepted $p$ value of .05 was adjusted based on the number of hypotheses. The Bonferoni adjustment was calculated by multiplying the $\mathrm{p}$ value of .05 by the number of hypothesis tests (e.g., $\frac{.05}{12}$ ). As a result, a more stringent $\mathrm{p}$ value level of .004 was employed to determine if there was a statistically significant difference between the two variables. Of the 12 proposed hypotheses, five hypotheses were confirmed (see Table 3). The results of the hypotheses tests will now be discussed in more detail by comparing the attribute pairs for each dimension. 
TABLE 3

HYPOTHESES TESTING

\begin{tabular}{|c|c|c|c|c|c|c|}
\hline $\begin{array}{c}\text { Hypothesis } \\
\text { Number }\end{array}$ & $\begin{array}{c}\text { Hypothesis } \\
\text { Concepts }\end{array}$ & $\begin{array}{l}\text { Proposed } \\
\text { Direction }\end{array}$ & $\begin{array}{l}\text { Mean } \\
\text { Score }\end{array}$ & $\begin{array}{l}\text { Direction } \\
\text { Confirmed }\end{array}$ & $\begin{array}{c}\text { P Value } \\
\text { Significance }\end{array}$ & $\begin{array}{l}\text { Hypothesis } \\
\text { Confirmed }\end{array}$ \\
\hline \multirow[t]{2}{*}{1} & Distributive & Higher & 0.29 & No & 0.0000 & No \\
\hline & Integrative & Lower & 10.26 & & & \\
\hline \multirow[t]{2}{*}{2} & Relational & Higher & 6.93 & No & 0.0000 & No \\
\hline & Task Related & Lower & 8.88 & & & \\
\hline \multirow[t]{2}{*}{3} & Older & Higher & 3.58 & Yes & 0.0000 & Yes \\
\hline & Younger & Lower & 2.15 & & & \\
\hline \multirow[t]{2}{*}{4} & Collectivist & Higher & 7.02 & Yes & 0.0000 & Yes \\
\hline & Individualist & Lower & 2.75 & & & \\
\hline \multirow[t]{2}{*}{5} & Consensus & Higher & 5.18 & Yes & 0.0000 & Yes \\
\hline & Centralized & Lower & 1.74 & & & \\
\hline \multirow[t]{2}{*}{6} & Polychronic & Higher & 1.59 & No & 0.0000 & No \\
\hline & Monochronic & Lower & 5.70 & & & \\
\hline \multirow[t]{2}{*}{7} & Risk Tolerant & Higher & 1.36 & No & 0.0000 & No \\
\hline & Risk Averse & Lower & 7.38 & & & \\
\hline \multirow[t]{2}{*}{8} & Fast Trust & Lower & 5.31 & No & 0.0000 & No \\
\hline & Slow Trust & Higher & 1.27 & & & \\
\hline \multirow[t]{2}{*}{9} & High Concern & Higher & 7.39 & Yes & 0.0000 & Yes \\
\hline & Low Concern & Lower & 0.61 & & & \\
\hline \multirow[t]{2}{*}{10} & High Context & Higher & 2.43 & No & 0.0000 & No \\
\hline & Low Context & Lower & 4.35 & & & \\
\hline \multirow[t]{2}{*}{11} & Factual Inductive & Lower & 8.31 & No & 0.0000 & No \\
\hline & Affective & Higher & 1.09 & & & \\
\hline \multirow[t]{2}{*}{12} & Complex & Higher & 2.49 & Yes & 0.0000 & Yes \\
\hline & Simple & Lower & 1.93 & & & \\
\hline
\end{tabular}

$\mathrm{H}_{1}$ assesses the basic negotiation concept dimension and suggests that Nigerian negotiators would be characterized as being more distributive (i.e., win/lose) rather than integrative in negotiation (i.e., seek mutually beneficial solutions). In fact, the Nigerian negotiating style seems to be exactly opposite of this proposed relationship. For example, the integrative variable (10.26) had the highest score (most like the Nigerian negotiating style) and the distributive variable (.29) had the lowest score (least like the Nigerian negotiating style). Thus, respondents showed a preference for integrative over distributive negotiation (M: 10.26 vs. 0.29$) \mathrm{t}=39.09(\mathrm{p}<0.004)$ and $\mathrm{H}_{1}$ is not supported.

$\mathrm{H}_{2}$ assesses the type of issue dimension and suggests that Nigerian negotiators would lean more toward relational rather than task-related issues. The results show that focusing on task-related more closely represents the Nigerian negotiation style over focusing on relational issues (M: 8.88 vs. 6.93) $\mathrm{t}=$ $7.47(\mathrm{p}<0.004) . \mathrm{H}_{2}$ is thus not supported.

$\mathrm{H}_{3}$ assesses the selection of negotiators dimension and suggests that Nigerians would lean more toward status rather than ability in selecting lead negotiators. The results show that selecting via status more closely represents the Nigerian negotiation style over selecting via ability (M: 3.58 vs. 2.15) $t=4.70$ $(\mathrm{p}<0.004) . \mathrm{H}_{3}$ is thus supported.

$\mathrm{H}_{4}$ assesses the influence of individuals' aspirations dimension and suggests that Nigerian negotiators would lean more toward collectivistic rather than individualistic solutions. The results suggest that collectivistically determined solutions more closely represent the Nigerian negotiation style over individually determined solutions (M: 7.02 vs. 2.75$) \mathrm{t}=8.61(\mathrm{p}<0.004) . \mathrm{H}_{4}$ is thus supported.

$\mathrm{H}_{5}$ assesses the decision-making process dimension and suggests that Nigerian negotiators would lean more toward consensus-building rather than centralized decision-making. The results suggest that 
consensus-building decision-making more closely represents the Nigerian negotiation style over centralized decision (M: 5.18 vs. 1.74) $\mathrm{t}=10.03(\mathrm{p}<0.004) . \mathrm{H}_{5}$ is thus supported.

$\mathrm{H}_{6}$ assesses the orientation towards time dimension and suggests that Nigerian negotiators would display a preference for polychronic (time is flexible) over a monochronic time-orientation (tasks should be handled during the scheduled time period). The results suggest that the respondents showed a preference for monochronic over a polychronic orientation towards time (M: 5.70 vs. 1.59) $t=12.45$ (p < $0.004)$. Thus, $\mathrm{H}_{6}$ is not supported

$\mathrm{H}_{7}$ assesses the risk-taking propensity dimension and suggests that Nigerian negotiators would be more risk-tolerant than risk-averse. The results suggest that respondents showed a preference towards risk-averseness over risk-tolerance $(\mathrm{M}: 7.38$ vs. 1.36$) \mathrm{t}=16.19(\mathrm{p}<0.004)$. Thus, $\mathrm{H}_{7}$ is not supported.

$\mathrm{H}_{8}$ assesses the speed of trust dimension and suggests that Nigerian negotiators would exhibit a preference for slower rather than faster speed of trust. Examining the conditions, we note that the respondents showed a preference for faster rather than slower speed of trust (M: 5.31 vs. 1.27) $t=9.28$ ( $p$ $<0.004)$. Thus, $\mathrm{H}_{8}$ is not supported.

$\mathrm{H}_{9}$ assesses the concern with protocol dimension and suggests that Nigerian negotiators would exhibit a preference for formal rather than informal protocol. Examining the conditions, we note that the respondents showed a preference for formal rather than informal protocol (M: 7.39 vs. 0.61$) t=28.68$ ( $p<$ 0.004). Thus, $\mathrm{H}_{9}$ is supported. (It should also be noted that the low concern for formal protocol variable had the second lowest score of all the variables).

$\mathrm{H}_{10}$ assesses the style of communication dimension and suggests that Nigerian negotiators would exhibit a preference for high-context (i.e., relatively little information in the message itself) rather than low-context (i.e., unlikely to be ambiguous) communication. Examining the conditions, we note that the respondents showed a preference for low-context rather than high-context communication (M: 4.35 vs. $2.43) \mathrm{t}=4.92(\mathrm{p}<0.004)$. Thus, $\mathrm{H}_{10}$ is not supported.

$\mathrm{H}_{11}$ assesses the nature of persuasion dimension and suggests that Nigerian negotiators would exhibit a preference for affective (i.e., likely to draw on feelings and beliefs to persuade) rather than factualinductive (e.g., if-then logic) persuasion tactics. The results show that factual-inductive persuasion more closely represents the Nigerian negotiation style over affective persuasion (M: 8.31 vs. 1.09) $\mathrm{t}=23.01$ ( $\mathrm{p}<$ $0.004) . \mathrm{H}_{11}$ is thus not supported.

$\mathrm{H}_{12}$ assesses the type of satisfactory agreement dimension and suggests that Nigerian negotiators would exhibit a preference for complex rather than simple agreements. The results show that complex agreements more closely represent the Nigerian negotiation desired solution style over simple agreements (M: 2.49 vs. 1.93) $\mathrm{t}=5.21(\mathrm{p}<0.004)$. Thus, $\mathrm{H}_{12}$ is supported.

\section{DISCUSSION}

This study is focused on developing a profile of Nigerian negotiators to better aid US firms in their negotiations with Nigerian businesses. Our study answers the call of Spralls et al. (2011) to confirm the validity of their findings. We tested a series of hypotheses to this effect, using the cultural dimensions model (Metcalf et al., 2008; Spralls et al., 2011; Weiss \& Strip, 1998). The results of the hypotheses tests allow us to get a better understanding of the dimensional profile of a Nigerian negotiator.

Focusing firstly on the supported hypotheses, we note that lead Nigerian negotiators will most likely be selected by status signals such as age and years of experience/seniority rather than by ability, as shown in $\mathrm{H}_{3}$. Nigeria is a high-hierarchical structure (Schwartz, 1999) and as such, the assignment of roles and resources follows the established hierarchy. This research shows that selecting lead negotiators in Nigeria also follows the existing hierarchical structure, wherein 'higher' age and 'higher' seniority ascribes higher status to an individual and thus makes them more likely to be selected (Madichie et al., 2008; Okoro \& Day, 2013). Similarly, Nigeria's highly hierarchical structure leads to an uneven power structure thus, creating a large distance between the 'powerful' and 'less-powerful' members of society (Hofstede et al., 2010; Onwumechili, 2018). In such a system, societal norms dictate that the less-powerful must treat the 
powerful members of society with deference. As such, negotiations, wherein these societal roles are evident, will be conducted with formal protocol; support for $\mathrm{H}_{9}$ confirms this assertion.

Support for $\mathrm{H}_{4}$ suggests that Nigerian negotiators generally seek collectivistic solutions, which are beneficial to all parties in an agreement. Considering that Nigerian culture as a whole is collectivistic (Brett, 2000; Hofstede et al., 2010), it is logical to expect elements of this collectivism to permeate most interactions that members of the culture engage in. Similarly, $\mathrm{H}_{5}$ is supported and once again we see the effects of Nigerian cultural collectivism on another interactive process; decision making in groups. Nigerians generally seek consensus-building when making important decisions (Bernard, 2013). Finally, we find support for the assertion that Nigerian negotiators will prefer complex to simple agreements in $\mathrm{H}_{12}$. We operationalize simple agreements as those where compensation in cash/stocks is simply given for completed work, and complex ones as those where compensation is contingent upon completed work plus extras such as improvement of socio-economic conditions. This preference for complex agreements once again highlights the collectivistic Nigerian culture, as negotiators see it as their duty to extract betterment for the common good from an entity with the power to provide that betterment. Indeed, Bernard (2013, p. 172), citing Lemos and Ribiero (2007, p. 64), laments that China, Africa's largest trading partner, is "undermining the lessons African nations have learned about the importance of transparency, social justice, and environmental sustainability."

With regard to the number of unsupported hypotheses, we note that the analytical procedure looked at "absolute" negotiating preferences rather than "relative" preferences. Absolute preference refers to which end of the spectrum on a particular issue does one gravitate toward/support/agree with. Measuring "absolute" preferences is critical in terms of establishing an accurate profile of the underlying negotiating style. The current study, however, did not examine "relative" preferences, i.e. how the Nigerian profile differs from those emanating from other cultures. For example, while the results indicate that Nigerians tend to be more task-oriented than relational in their negotiations (contrary to our hypothesis $\mathrm{H} 2$ ), the extent of this task orientation could very well be weaker/more relational than Americans tend to exhibit. While the current study contributes to the literature by establishing a profile of the Nigerian negotiator, future studies could build on this by examining how this profile differs from those of other cultures. Thus, while the research findings did not support some hypothesized "absolute" preferences (i.e., no evidence Nigerians employ relational rather than task-oriented negotiating) it does not rule out the possibility that some "relative" preferences may exist (i.e., Nigerians tend to employ a task-oriented negotiating style but future research might show it is less task-oriented than those used in other cultures).

Revisiting the unsupported hypotheses, we see that Nigerian negotiators prefer an integrative negotiating process to a distributive process. Contrary to the extant research suggesting that Nigerian negotiators would view the negotiation as a zero-sum/must-win situation (Salacuse, 1998; Weiss \& Stripp, 1998), this research shows that Nigerians overwhelmingly displayed a preference for an integrative (mutually beneficial) negotiation process. This unsupported result might be explained by once again considering the collectivistic culture of Nigeria. The same drive that pushes Nigerian negotiators to seek collectivistic solutions rather than pursuing individual aspirations might be driving their overall basic approach to negotiations. On the other hand, the graduate students we sampled, may be relatively inexperienced at negotiating. Over time, they may become more distributive in their negotiating style. Further research is needed using a sample of industry professionals.

Further, a lack of support for $\mathrm{H}_{2}$ suggests that Nigerian negotiators focus more on task-related over relational issues. While the prevailing view in research is that building relationships is central to the Nigerian cultural view on success and advancement (e.g., Salacuse, 1998), we suggest that this relational view is primarily adopted in attaining desired positions (success) and career progress. Once actually on the job, the focus shifts to doing all one must to be successful ergo, focusing on successfully completing task-related issues.

Lack of support for $\mathrm{H}_{6}$ suggests that Nigerian negotiators will tend towards a monochronic over a polychronic time orientation. While previous research has indicated that Nigerians have a relaxed attitude towards time (Spralls et al., 2011), a rapidly negatively evolving economic macroenvironment has caused a lot of value to be placed on acquiring money, consequently, on the time required to attain said money. 
At a deeper level, our measure for polychronic may not have been sufficient to capture Nigerian's attitude toward time. For Igbos, the day is not broken into measurable time segments, rather, the day is categorizable by visibly recognizable segments such as morning (Ututu). Thus, the sense of time is guided by this categorization of time. For example, in the village, events are scheduled by "times" such as ututu. One implication of this is that people do not all arrive at the same moment the event starts and yet are considered "on time" (Onwumechili, 2018).

Similarly, the result of testing $\mathrm{H}_{7}$ suggests that Nigerian negotiators will tend towards risk-averseness over risk-tolerance. While previous research suggests a Nigerian tendency towards risk-tolerance (Salacuse, 1998), the aforementioned economic realities may have led to a fear of entering deals that could be economically risky. Some Nigerian negotiators may delay decisions on potentially high-reward deals, for fear of making bad decisions. On the other hand, Madichie et al., (2008, p. 286), describe the Igbos of Anambra state, eastern Nigeria as having "strong entrepreneurial spirit, which makes them venturesome and daring in business risk taking." Thus, more research is needed to better understand the risk-taking propensity of Nigerians and its effect on Nigerian negotiating style.

Further, previous research has suggested that Nigerian negotiators would be slow in developing trust for parties on the other side of the deal, and that while contracts are necessary to develop trust, they are insufficient in and of themselves (Egunjobi \& Odiaka, 2015; Spralls et al., 2011). We contend however that since Nigerians put significant stock in both relationship development and trying to avoid making bad decisions, by the time a contract is signed, trust between the parties will already be established (Bernard, 2013). Some inherent confusion exists due to the conceptualization of this construct with a focus on speed. Perhaps a more apt way to view this construct would be 'conditions necessary for trust development.' Indeed, Egunjobi and Odiaka (2015, p. 41), note 'It is imperative to highlight here that the culture of negotiation hangs on four main stands, which includes respect for the other party thereby gaining trust, compromise, willingness to budge, and relationships. All negotiation processes are expected to be built on these premises." Also, contrary to the extant research, the results in this study suggest that Nigerian negotiators will tend to exhibit a low-context over high-context communication style. Simply explained, since Nigerian negotiators tend to be higher-status societal members, they do not see the need to defer to anyone or be less than direct in communicating their opinions. Then too, the low context/high context dichotomy may not be sufficient to capture the nuance of Igbo communications. Indeed, nonverbal communication, for Igbos, not only compliments verbal communication it may be necessary to make sense of the verbal communication. Thus, the cut-eye, suck-teeth gesture, and even silence may provide context (Okoro \& Day, 2013; Onwumechili, 2018).

Finally, the data in this study overwhelmingly suggests, counter to the extant research, that Nigerian negotiators tend towards factual-inductive over affective arguments in their persuasion strategies. We contend, however, that this is a research artifact of a social-desirability bias, and that it does not reflect the true nature of the Nigerian negotiator.

\section{IMPLICATIONS}

\section{Implications for Theory}

The results extend the intercultural negotiation and negotiating style literatures by providing an empirically validated Nigerian negotiator profile. This is a necessary first step before meaningful crosscultural comparisons can be made. We contribute to existing knowledge about international business negotiations in at least two major ways. First, we made further improvements, refinements and modifications to the Weiss \& Stripp $(1985,1998)$ twelve-dimension framework as modified by Metcalf et al. (2008). More specifically, we provided empirical support for Nigerian: (1) selection of negotiators by status, (2) formal concern with protocol, (3) the influence of individual aspirations being collectivist, (4) decision making by majority rule, and (5) complex type of satisfactory agreement. Although seven our hypotheses (i.e., $\mathrm{H}_{1}, \mathrm{H}_{2}, \mathrm{H}_{6}, \mathrm{H}_{7}, \mathrm{H}_{8}, \mathrm{H}_{10}$, and $\mathrm{H}_{11}$ ) were not supported, because of the nature of our study (i.e., MDS), we learned that Nigerians negotiation tendencies include: (1) integrative basic concept of negotiations, (2) a task most significant type of issue, (3) monochronic time orientation, (4) risk adverse 
risk-taking propensity, (5) fast speed of trust, and (6) low context style of communication. Second, we identified, and attempted to resolve, apparent contradictions in the literature.

\section{Implications for Practice}

Our study makes possible culturally responsive strategy prescriptions, where strategy is the overall orientation given by an actor to achieve his/her goal (Berton, Kimura, \& Zartman, 1999). A culturally responsive strategy should be designed to align the parties' negotiating scripts or otherwise bring about a mutually coherent form of negotiator interaction (Weiss \& Stripp, 1994). We assist in learning the negotiation script of Nigerians, particularly those of the Igbo tribe. Indeed, our findings may be used to predict Nigerian negotiating behaviors in international negotiations.

Our findings can be used to enhance global negotiator effectiveness in a number of ways. Regarding selection of negotiators, as Nigerians value status over ability in selecting negotiators, international firms should take care in selecting representatives that present tangible status signals to their Nigerian counterparts. These signals could be shown simply by selecting older negotiators to engage with the Nigerians; such a negotiator will garner more respect purely due to age (Weiss \& Strip, 1998). Alternatively, status could be conveyed in the form of job or other titles that indicate membership in a higher class; Nigerians would be more apt to negotiate with a "senior managing director," "PhD.," or "vice president" etc. The higher hierarchical status specified by said titles are simply more appealing to Nigerians (Schwartz, 1999).

Similarly, regarding formal concern with protocol, due to the presence of high-status and lower-status individuals in the negotiation process, the power distance suggests that the proceedings will generally be formal. Conducting intercultural negotiations in Nigeria should thus be approached from a formal position. As Nigerians also value building long-term, more than simply transactional relationships (Spralls et al., 2011), there might be informal activities carried out away from the negotiation table; American negotiators should be savvy enough to adjust (Adler, 2002) to a less formal position when such activities arise.

Regarding individual aspirations and decision-making, this research shows that Nigerian negotiators generally seek collectivistic solutions over individually focused ones. Nigeria's relatively collectivistic culture (Brett, 2000; Hofstede et al., 2010) explains why Nigerians seek consensus-building and collective solutions, even in the presence of high power distance between those with status and those without. American negotiators seeking to do business in Nigeria should make sure to promote a democratic process in arriving at a solution; they should, at the very least, convey that all opinions and potential solutions are equally valued.

Finally, we show in this research that Nigerian negotiators are more apt to accept complex vs. simple agreements. These complex agreements go beyond simple transactional exchanges and include various socio-economic development initiatives such as: building infrastructure for educational purposes, improving medical care etc. American Negotiators should do their due diligence in anticipating these demands and establishing the means and resources to cover such agreements. These demands can vary widely thus, it is also important that the agreement terms are clearly defined.

In summary, we enhanced practitioner effectiveness by assisting negotiators in performing cultural due diligence and better understanding the need for cultural mentoring.

\section{LIMITATIONS AND FUTURE RESEARCH}

Several limitations are evident in our study. First, all measures are from a single source, Nigerian MBA and MBA-level students. Therefore, it is possible that the students lack of experience may have softened some of the responses as a result of this aspect of our design. Additionally, it is possible the students responded to our questions with what they learned from their curriculum to be best business

practice rather than their own internal culturally driven negotiating preferences. Similarly, a sample of MBA/MBA-level students might not truly represent the overall population of Nigerian negotiators, some of who may not possess advance degrees or had recent training. 
Further, although we tried to ensure understanding and clarity by pre-testing our survey and having the instructions read out loud to respondents, our analysis assumes that all respondents fully understood the MDS questions and answered them correctly to reveal their best and worst choices. We also did not consider gender bias in our discussion. Janosik (1987, p. 392) cautions that "nationality/culture does have an important role to play, but any generalizations about the nationality/culture nexus might require modifications to account for age, gender, and the negotiating environment." Indeed, our sample had a large percentage of males (65\%) but given that Nigeria is a male dominant society (Okoro \& Day, 2013), our findings should be no less valuable.

Finally, although our study tapped into Nigerian negotiator tendencies, it did not measure their actual behavior and given that intentions and behavior do not always intersect, some caution in interpreting our findings may be necessary. That notwithstanding, the present research raises questions that need to be answered in more detail in future studies.

Future research could make cross-cultural comparisons of the Nigerian negotiating profile and how it differs from those of other cultures. Additionally, MDS could be used to segment Nigerian negotiators based on the negotiation attributes most important (or least important) to them. This would allow Americans to develop separate strategies for effectively negotiating with each group. Given the stark cultural differences between the different tribes in Nigeria, the MDS generated segments might correlate with tribal segments. It might thus be productive to replicate this study using a balanced sample with multi-tribal representation.

Researchers can also investigate the conditions necessary for the development for trust and determine factors useful for developing long-term relationships with a party who has been "burned" repeatedly. This touches on, but is not limited to, issues of perceived fairness, interpretation of outcomes (Berton et al., 1999), and finding ways to make sure both parties respect contract provisions. Future research can also investigate whether individuals' negotiating style can change over time; a longitudinal study would be useful as would a sample of people in industry (e.g., the oil industry). At the very least, research is needed to explore the compatibility of Nigerian and U.S. negotiating orientations (Weiss \& Stripp, 1998) and make strategy prescriptions.

In conclusion, firms are increasingly forming collaborative agreements with companies in Nigeria to acquire and maintain competitive advantage. Our research findings are useful to global managers and business owners, planning to do business in Nigeria, or with Nigerians, because it sheds light on the predominant Nigerian negotiating style that U.S. negotiators are likely to encounter. Studies that replicate and extend our research are called for. As globalization and economic interdependence continues to proliferate, such research should be of increasing value.

\section{ACKNOWLEDGEMENTS}

The authors gratefully acknowledge the assistance provided by Dr. Patrick Okonkwo, Professor Emeritus, Central Michigan University. Dr. Okonkwo was extremely helpful to our efforts to collect the data for this study in Nigeria. 


\section{REFERENCES}

Acuff, F.L. (1997). How to negotiate anything with anyone anywhere around the world, NY: American Management Association.

Adair, W.L., \& Brett, J.M. (2005). The negotiation dance: Time, culture, and behavioral sequences in negotiation. Organization Science, 16, 33-51.

Adler, N.J. (2002). International dimensions of organizational behavior (4th ed.), Cincinnati: SouthWestern.

Bazerman, M.H., \& Neale, M.A. (1992). Negotiating rationally, NY: Wiley.

Bernard, P.E. (2013). Muntu meets mencius: Can ancient principles guide modern negotiations on the export of Africa's natural resources to China? In Honeyman, Christopher; Coben, James; and Wei-Min Lee, Andrew (Eds.), Educating Negotiators for a Connected World: Volume 4 in the Rethinking Negotiation Teaching Series (pp. 171-216). DRI Press. Book 5.

Berton, P., Kimura, H., \& Zartman, I.W. (Eds.) (1999). International negotiation: Actors, structure, process, values. NY: Bedford/St. Martin's.

Binnendijk, H. (Ed.) (1987). National negotiating styles. Washington DC: U.S. Department of State.

Brautigam, D. (1997). Substituting for the state: Institutions and industrial development in eastern Nigeria. World Development, 25(7), 1063-1080.

Brett, J.M. (2000). Culture and negotiation. International Journal of Psychology, 35(2), 97-104.

Bulow, A.M., \& Kumar, R. (2011). Culture and negotiation. International Negotiation, 16(3), 345-359.

Cellich, C. \& Subhash C.J. (2004). Global business negotiations: A practical guide. Mason: SouthWestern.

Cheung, K.L., Wijnen, B.F., Hollin, I.L., Janssen, E.M., Bridges, J.F., Evers, S.M., \& Hiligsmann, M. (2016). Using best-worst scaling to investigate preferences in health care. Pharmacoeconomics, 34(12), 1195-1209.

Chrzan, K., \& Golovashkina, N. (2006). An empirical test of six stated importance measures. International Journal of Market Research, 48, (6), 717-740.

Chrzan, K., \& Patterson, M. (2006). Testing for the optimal number of attributes in MaxDiff questions. Proceedings of the 12th Annual Sawtooth Software Conference, Delray Beach, FL, March 29-31, 63-8.

Egunjobi, L., \& Odiaka, N.O. (2014). The negotiation issues in Nigeria post-independence conflicts. Journal of Global Initiatives: Policy, pedagogy perspective, 9(2), 33-46.

Eliasberg, J., Lilien, G., \& Kim, N. (1995). Searching for generalizations in business marketing negotiations. Marketing Science, 14(3), G47-G60.

Fang, T. (1998). Chinese business negotiating style. Thousand Oaks, CA: Sage.

Faure, G.O. (1998). Negotiation: The Chinese concept. Negotiation Journal, 14(2), 137-148

Garver, M.S., Williams, Z., \& LeMay, S.A. (2010). Measuring the importance of attributes in logistics research. International Journal of Logistics Management, 21(1), 22-44.

Gelfand, M.J., Brett, J., Gunia, B.C., Imai, L., Huang, T-J., \& Hsu, B.-F. (2013). Toward a culture-bycontext perspective on negotiation: Negotiating teams in the United States and Taiwan. Journal of Applied Psychology, 98(3), 504-513.

Gelfand, M.J., \& Dyer, N. (2000). A cultural perspective on negotiation: Progress, pitfalls, and prospects. Applied Psychology: An International Review, 41(1), 62-99.

Ghauri, P., \& Fang, T. (2001). Negotiating with the Chinese: A socio-cultural analysis. Journal of World Business, 36(3), 303-325.

Graham, J.L., Mintu, A.T., \& Rodgers, W. (1994). Explorations of negotiation behaviors in ten foreign cultures using a model developed in the United States. Management. Science, 40(1), 72-95.

Gudykunst, W.B., Matsumoto, Y., Ting-Toomy, S., Nishida, T., Kim, K., \& Heyman, S. (1996). The Influence of cultural individualism-collectivism, self-construals, and individuals values on communication styles across cultures. Human Communication Research, 22(4), 510-543. 
Hofstede, G., Hofstede G. J., \& Minkov, M. (2010). Cultures and organizations: Software of the mind. Revised and Expanded 3rd Edition. New York: McGraw-Hill.

Janosik, R.J. (1987). Rethinking the culture-negotiation link. Negotiation Journal, 3(October), 385-395.

Katwalo, A.M., \& Madichie, N. (2008), Entrepreneurial and cultural dynamics: a gender kaleidoscope of Ugandan microenterprise. International Journal of Entrepreneurship and Small Business, 5(3/4), 337-348.

Lemos, A. \& Ribiero, D. (2007). China's investment in Sudan: Displacing villages and destroying communities. In African Perspectives on China in Africa, edited by F. Manji and S. Marks. Oxford: Fahamu Books.

Luomala, H.T., Kumar, R., Singh, J.D., \& Jaakkola, M. (2015). When an intercultural business negotiation fails: Comparing the emotions and behavioural tendencies of individualistic and collectivistic negotiators. Group Decision and Negotiation, 24(3), 537-561.

Madichie, N., Nkamnebe, A.D., \& Idemobi, E. (2008), Cultural determinants of entrepreneurial emergence in a typical sub-Sahara African context. Journal of Enterprising Communities: People and Places in the Global Economy, 2(4), 285-99.

Mahajan, V. (2009). Africa rising. Upper Saddle River, NJ.: Wharton School Publishing.

Metcalf, L.E., Bird, A., \& Dewar, D. (2008). Mexico and the United States: Common border, common negotiating orientations. Thunderbird International Business Journal, 50(1), 25-43.

Metcalf, L.E., Bird, A., Shankarmahesh, M., Aycan, Z., Larimo, J., Valdelamar, D.D. (2006). Cultural tendencies in negotiation: A comparison of Finland, India, Mexico, Turkey, and the United States. Journal of World Business, 41, 382-394.

Moran, R.T., \& Stripp, W.G. (1991). Successful international business negotiation. Houston: Gulf.

Morgan, R.M., \& Hunt, S.D. (1994). The commitment-trust theory of relationship marketing. Journal of Marketing, 58 (July), 20-38.

Munene, J.C., Schwartz, S.H., \& Smith, P.B. (2000). Development in sub-Saharan Africa: Cultural influences and managers decision behaviour. Public Administration \& Development, 20(4), 339351.

Ndulu, B.J. (2007). Challenges of African growth: Opportunities, constraints, and strategic directions. Washington DC. The World Bank.

Nnadozie, E.A. (1998). African culture and American business in Africa: How to strategically manage cultural differences in African business, Kirksville: Afrimax, Inc.

Nwankwo, S. (2000). Assessing the marketing environmental in sub-Saharan Africa: Opportunities and threats analysis. Marketing Intelligence and Planning, 18(3), 144-153.

Okoro, E. (2013). Negotiating with global managers and entrepreneurs in sub-Saharan Africa - Nigeria: An analysis of nonverbal behavior in intercultural business communication. International Journal of Academic Research in Business and Social Sciences, 3(8).

Onwuejeogwu, M.A. (1995). Development in Africa: Common cultural values central for effective managerial and administrative training programmes. Paper presented at a regional seminar on cultural dimensions and appropriate and effective management in Africa. Makerere University, Kampala, Uganda.

Onwumechili, C. (2018). Dynamism: N'digbo and communication in post-modernism. In Kehbuma Langmia (Ed.), Black/Africana Communication Theory, NY: Spring International Publishing, 173-190.

Rudd, J.E., \& Lawson, D.R. (2007). Communicating in global business negotiations: A geocentric approach. Thousand Oaks, CA: Sage.

Salacuse, J.W. (1998). Research report: Ten ways that culture affects negotiating style: Some survey results. Negotiating Journal, 14, 221-240.

Sawyer, J., \& Guetzkow, H. (1965). Bargaining and negotiation in international relations. In H.C. Kelman (Ed.), International Behavior: A Social-Psychological Analysis, NY: Holt, Rinehart and Winston, 465-520.

126 Journal of Applied Business and Economics Vol. 21(5) 2019 
Schwartz, S.H. (1999). Cultural value differences: Some implications for work. Applied Psychology: An International Review, 48, 23-47.

Spralls III, S.A., Okonkwo, P., \& Akan, O.H. (2011). A traveler to distant places should make no enemies: Toward understanding Nigerian negotiating style. Journal of Applied Business and Economics, 12(3), 1-25.

Tung, R.L. (1982). U.S.-China trade negotiations: Practices, procedures, and outcomes. Journal of International Business Studies, 10(3) Fall, 25-37.

Weiss, S.E., \& Stripp, W. (1998). Negotiating with foreign business persons. In Niemeier, S., Campbell, C.P., \& Dirven, R. (Eds.), The Cultural Context in Business Communication (pp. 95-118), Philadelphia, PA: John Benjamins.

Weiss, S.E. (1994). Negotiating with the Romans-Part1. Sloan Management Review, 35(2) Winter, 51-62.

Weiss, S.E. (1993). Analysis of complex negotiations in international business: The RBC perspective. Organization Science, 4(2) (May), 269-282.

Weiss, S.E., \& W. Stripp. (1985). Negotiating with foreign businesspersons: An introduction for Americans with propositions on six cultures. New York University Working Paper 85-6. 